\title{
Biology Teachers' Workload and Academic Performance of Secondary School Students in Abia State
}

\author{
Dr. O.F. Ndioho and Chukwu, Joy.C \\ Department of Curriculum Studies and Educational Technology, Faculty of Education University of Port \\ Harcourt P.M.B 5323 Port Harcourt
}

\begin{abstract}
This study was carried out to determine Teachers' workload and academic performance of secondary school students in Biology. It was conducted in University of Port Harcourt Rivers State, Nigeria. The sample comprised of 220 Biology teachers which was purposively selected randomly from three educational zones (rural and urban locations) in Abia State. Two research objectives and two hypotheses were used in the study. The data was analyzed using mean and rank order statistics to answer the research questions while z-test statistics was used to test the hypotheses at 0.05 level of significance. The reliability co-efficient obtained using Pearsons product moment co-relation coefficient was 0.70. The study found that teachers' workload has effects on students' performance in Biology. In addition, it was found that teachers' supply have great influence on students' academic performance. It was recommended amongst others that in order to reduce teachers' workload, Biology teachers should only teach a particular arm of class as this will enable the teachers' cope with the stress of the workload.
\end{abstract}

Keywords: Workload, Teachers' supply, academic performance.

\section{Introduction}

Education is for life and for the living. It is an investment in people which pays immeasurable dividend to the society but when that investment is not made or is inadequately made, the society involved suffers a great deal of loss Adeyemo (2012).

An aspect of human resources management in the school is the workload of the staff. This is the amount of work assigned to a teaching position. Teaching staff workload includes teaching subjects, administrative duties, supervision of students and other activities. Naylor and Malcomson (2001) revealed that teachers saw their workload increased because they spent fifty-three hours a week preparing their lesson notes for teaching and marking scripts. The teachers reported that their activities needed to be reduced to enable them cope with the stress of the workload because when stress sets in it was difficult for them to accomplish all their objectives due to lack of time. Consequently, the performance of the teachers and the students were impaired.

A significant and consistent relationship exists in the academic achievement of students in small classes of 1-20 students that obtained higher scores in science test than their counterparts in large classes of more than 20 students Gbore and Daramola (2013).

When a teacher teaches a class of over 70 students, the teacher is faced with the challenges of class control, assessing and evaluating students in class. This difficulty arises because too many students in the same class reduces a teacher's ability to access each of the students individually and also monitor the student to identify the student's area of weakness and strength. This leads to demotivation of the subject teacher hence affecting the students' performance.

Usman (2003) asserted that inadequate teachers' supply is responsible for the poor academic performance observable among students while research findings have shown that teachers' turnover (leaving for other professions) is always high because many teachers tend to leave the teaching profession if and when more attractive jobs become available in government, politics or private enterprise Adeyemi (2011). Thus, teacher's turnover is capable of leading to serious teachers' short supply in schools.

A close observation at the demand and supply situations of teachers in Nigerian schools tends to reveal a disparity in the distribution of teachers to schools. The addition of new subjects into the curricula of many schools and the introduction of the continuous assessment as a means of evaluating students' performance and retirement of teachers without employment of new teachers as replacement for the retired teachers have led to the demand for more teachers.

\section{Statement of the problem}

While knowledge of science is the bedrock of all technological advancement, Biological knowledge and practice are essential to building a suitable relationship between nature and human society. The teaching of Biology education should be programmed in a way that it will create time and less workload for the teacher in this $21^{\text {st }}$ century. 
The science curriculum in secondary schools has been improved upon in recent years in both objectives and content. There is no gain saying that no matter how good a curriculum plan may be, its implementation is very crucial to its success. Teachers as agents of curriculum implementation are very important so also is their availability to both urban and rural secondary schools where their services are immensely important. It has been discovered that at the moment we do not have enough number of Biology teachers in secondary schools despite the growing number of students and the compulsory nature of the subject in the school system. Many teachers would now have to cope with large classes which translate to poor performance and create negative disposition towards learning Biology. Based on this, the study will seek to investigate Biology teacher's workload, Biology teachers supply and academic performance of secondary school students in Biology in Abia State.

\section{Aim and objectives}

1. To determine teachers' workload and academic performance of secondary school students in Biology.

2. To examine teachers' supply and academic performance of secondary school students in Biology

\section{Research questions}

1. Do teachers' workloads affect academic performance of secondary school students in Biology?

2. What is the effect of teachers' supply on academic performance of secondary school students in Biology?

\section{Hypotheses}

1. There is no significant difference between the effect of teachers' workload of rural and urban teachers on academic performance of secondary school students in Biology.

2. There is no significant difference between the effect of teachers' supply in rural and urban locations on academic performance of secondary school students in Biology.

\section{Methodology}

The purpose of this study was to ascertain Biology teacher's workload and academic performance of secondary school students in Biology. The study area was in Abia State in the south eastern part of Nigeria. The population of the study included all the four hundred and fifty eight (458) Biology teachers in the two hundred and twenty nine (229) public secondary schools spread across the three (3) educational zones in Abia State, namely Umuahia, Aba and Ohafia. The sample comprised 220 respondents randomly selected from each educational zone which constituted a stratum and each stratum included urban and rural teachers. Stratified random sampling technique was applied in the selection process. A structured questionnaire was used as research instrument. The questionnaire was structured using modified likert type four point rating scale $(4,3,2,1)$ as of Strongly agree, agree, disagree, strongly disagree respectively. An acceptable mean of 2.50 was used in the study.

\section{Results and discussion}

Table 1.1a: Teachers workload and academic performance of secondary school students in Biology

\begin{tabular}{|l|l|l|l|l|l|l|l|}
\hline $\mathbf{S} / \mathbf{N}$ & \multicolumn{1}{|c|}{ Items } & \multicolumn{1}{|c|}{ Urban Teachers } & \multicolumn{1}{|c|}{ Rural Teachers } & \multicolumn{1}{|c|}{ Rank } \\
\hline & \multicolumn{1}{|c|}{$\mathbf{N}$} & $\mathbf{X}$ & $\overline{\boldsymbol{X}}$ & \multicolumn{1}{|c|}{$\mathbf{X}^{\text {th }}$} \\
\hline 1 & Teachers have heavy teaching load & 220 & 1.90 & 220 & 2.37 & 2.14 & $5^{\text {rd }}$ \\
\hline 2 & $\begin{array}{l}\text { teacher mainly focus on course coverage } \\
\text { Teachers find difficult and stressful in giving } \\
\text { assignment and marking them. }\end{array}$ & 220 & 2.81 & 220 & 3.13 & 2.97 & $3^{\text {rd }}$ \\
\hline 4 & $\begin{array}{l}\text { Teachers are discouraged in teaching large } \\
\text { classes and controlling them. }\end{array}$ & 220 & 3.17 & 220 & 3.08 & 3.13 & $4^{\text {st }}$ \\
\hline 5 & $\begin{array}{l}\text { Biology teachers teach more than one science } \\
\text { subject }\end{array}$ & 220 & 3.02 & 220 & 3.05 & 3.04 & $2^{\text {nd }}$ \\
\hline
\end{tabular}

From the above table, the high mean scores ranging from 2.14 to 3.13 indicated that some of the items identified were accepted as teachers' workloads affect performance of secondary school students in Biology. Hence the mean scores were above criterion mean. While only item 1 was not accepted as teachers' workloads. This is because the mean score was less than the criterion mean. It is evident that teachers' workload affect students' performance in Biology.

Hypothesis 1: There is no significant difference between the effect of teachers' workload of rural and urban teachers on academic performance of secondary school students in Biology. 
Table 1.1b: Mean, standard deviation and z-statistic on teachers' workload and secondary school students' performance in Biology.

\begin{tabular}{|l|c|c|c|c|c|c|c|c|}
\hline & $\mathbf{N}$ & $\overline{\boldsymbol{X}}$ & SD & Z-cal & Z-cri & DF & Level sign. & Decision \\
\cline { 1 - 8 } Urban teachers & 220 & 2.79 & 0.62 & 1.75 & 1.96 & 88 & 0.05 & $\mathrm{H}_{0}$ was accepted \\
\cline { 1 - 5 } Rural teachers & 220 & 2.86 & 0.71 & & & & & \\
\hline
\end{tabular}

The data in table $1.1 \mathrm{~b}$ above, shows that the $\mathrm{z}$-calculated value of 1.75 is less than $\mathrm{z}$-critical value of 1.96 at 0.05 level of significance with 88 degree of freedom. The null hypothesis $\left(\mathrm{H}_{0}\right)$ was accepted. This means that there is no significant difference between the effect of teachers' workload of rural and urban teachers on academic performance of secondary school students in Biology.

Table 1.2a: Teachers' supply and academic performance of secondary school teachers in Biology

\begin{tabular}{|c|c|c|c|c|c|c|c|}
\hline \multirow[t]{2}{*}{$\mathbf{S} / \mathbf{N}$} & \multirow[t]{2}{*}{ Items } & \multicolumn{2}{|c|}{ Urban Teachers } & \multicolumn{2}{|c|}{ Rural Teachers } & \multirow{2}{*}{$\bar{X} \bar{X}$} & \multirow[t]{2}{*}{ Rank } \\
\hline & & $\mathbf{N}$ & $\bar{X}$ & $\mathbf{N}$ & $\bar{X}$ & & \\
\hline 1 & Teachers supply to schools should be on subject basis & 220 & 3.02 & 220 & 3.13 & 3.08 & $1^{\mathrm{st}}$ \\
\hline 2 & $\begin{array}{l}\text { Teachers' supply should be based on specialization } \\
\text { while posting teachers to schools }\end{array}$ & 220 & 3.19 & 220 & 2.94 & 3.07 & $2^{\text {nd }}$ \\
\hline 3 & $\begin{array}{l}\text { Biology subjects should be given more priority in the } \\
\text { posting of teachers to schools. }\end{array}$ & 220 & 2.43 & 220 & 2.47 & 2.45 & $4^{\text {th }}$ \\
\hline 4 & Teachers' supply favoured urban schools. & 220 & 2.97 & 220 & 2.72 & 2.85 & $3^{\text {rd }}$ \\
\hline
\end{tabular}

From the table above, the high mean scores ranging from 2.45 to 3.08 indicated that some items identified were accepted as the effect of teachers' supply on the academic performance of secondary school students in Biology. Hence, the mean scores were above the criterion mean. While only two items were not accepted as the effect of teachers' supply. This is because the mean scores were less than the criterion mean. It is evident that teachers' supply required attention in aspect of location.

Hypothesis 2: There is no significant difference between the effect of teachers' supply in rural and urban locations on academic performance of secondary school students in Biology.

Table 1.2b: Mean, standard deviation and z-statistics on teachers' supply and academic performance of secondary school students in Biology.

\begin{tabular}{|l|c|c|c|c|c|c|c|c|}
\hline & $\mathbf{N}$ & $\overline{\boldsymbol{X}}$ & SD & Z-cal & Z-cri & $\mathbf{D F}$ & Level sign. & Decision \\
\cline { 1 - 5 } Urban teachers & 220 & 2.80 & 0.67 & 1.46 & 1.96 & 88 & 0.05 & $\mathrm{H}_{0}$ was accepted \\
\hline Rural teachers & 220 & 2.74 & 0.73 & & & & & \\
\hline
\end{tabular}

The data in table $1.2 \mathrm{~b}$ above shows that the $\mathrm{z}$-calculated value of 1.46 is less than $\mathrm{z}$-critical value of 1.96 at 0.05 level of significance with 88 degree of freedom. The null hypothesis $\left(\mathrm{H}_{0}\right)$ was accepted. This means that there is no significant difference between the effect of teachers supply in urban and rural locations on academic performance of secondary school students in Biology.

The findings of the study revealed that teacher's workloads affect students' performance. Naylor and Malcomson (2001), discovered that teachers saw their workload increased because they spent fifty-three hours a week preparing their lesson notes for teaching and marking scripts. The teachers reported that they modified their teaching methods to enable them cope with the stress of the workload. When that happened, it was difficult for them to accomplish all their objectives because of lack of time. Consequently, the performance of the teachers and the students was impaired. This finding agreed with Ajayi (1999) which revealed that no significant difference exists between teachers' workload and students' academic performance while Kolawole (1982) found that a negative relationship exists between the academic performance of students and class size.

The study further revealed that teachers' supply require attention in aspect of location. Common observation in the public secondary school system in the state shows that teachers usually prefer to work in schools located in urban areas rather than the rural areas. This is perhaps due to the presence of many social amenities and infrastructural facilities in the urban areas and the desire for their wards to obtain their education in the urban areas.

Many reasons have been attributed to teachers leaving the teaching profession (Adeyemi 2011). Some of these reasons include poor conditions of service, low social status in the society, lack of incentives, poor salary, delayed promotional prospects and delayed payment of salaries. Commenting on these points, Adeyemi (2008) explained that many teachers leave the teaching profession due to discouragement and frustration resulting from low social status accorded the teaching profession in the society which was not so in the past. The finding of this study agreed with Nwachukwu (2009) that teachers' professional competencies for education effectiveness have shown that teachers are always in short supply in schools and their turnover is high because 
they tend to leave the teaching profession if and when more attractive jobs become available in government, politics or private enterprise.

\section{Conclusion}

The following conclusions were made by the researchers

- The teachers' resorts to reduce teaching methods to one rather than teach the students using two or more teaching methods, reduced number of assessments and mutilated lesson delivery to enable them cope with the stress of the workload.

- There is disparity of teachers' supply to schools. Biology subjects should be given more priority in the posting of teachers to urban and rural schools. This will enable the teachers to cover the syllabus before the students take the examinations.

\section{Recommendations}

- In order to reduce teacher's workloads, Biology teachers should only teach a particular arm of class, for example, if it is SS1, the teacher should teach only that class. This will create room for the teacher to handle the individual difference of the students and also create room for research and new innovation from the teachers.

- Reduced Biology teachers' workload will enable the teacher to handle classroom teaching, practical class teaching and concise explanations of rudiments of Biology concepts. This will enable students to overcome examination phobia and uncertainty in their examinations.

- The State Government should make it mandatory on any Biology teacher not to refuse posting to any part of the state, whether urban or rural. This is to correct the disparity in the supply of qualified and experienced Biology teachers between urban and rural schools.

\section{References}

[1]. Adeyemi, T.O. (2008). The influence of class - size on the quality of output in secondary schools in Ekiti State, Nigeria. American_Eurasian Journal of Scientific Research 3 (1):7-14.

[2]. Adeyemi, T.O. (2011). "Teachers' job satisfaction and job performance in secondary schools in Ekiti State, Nigeria." International Journal of Afro-Asian Studies. USA: Brown Walker Press. 2(2); 41-51.

[3]. Adeyemo, S.A. (2012). Te influence of teachers' supply and the provision of laboratory facilities on students' achievement in physics. European Journal of Educational Studies. Vol. 4(3): 397-408.

[4]. Ajayi, I.A. (1999). Teachers' assessment of parent's teachers association roles in administration of secondary schools. Journal of Educational Research and Evaluation 3(2), 110-116.

[5]. Gbore, L.O. and Daramola, C.A. (2013). Relative contributions of selected teachers variables and students, attitudes towards academic achievement in Biology among senior secondary school students in Ondo State, Nigeria. Current issues in education vol. 16 (1) $1-9$.

[6]. Kolawole, S.K. (1982). Impact of class size on student's achievement in secondary schools in Ibadan. Unpublished M.Ed. Thesis University of Ibadan.

[7]. Naylor, C. \& Malcomson, J.D. (2001). A study of workload of English teachers in B.C. secondary grades. BCTR research report. RTO 1-0036 pp 16-17.

[8]. Nwachukwu, P.O. (2009). Understanding teachers' professional competencies for education effectiveness. Owerri: Spring field publishers, 2009

[9]. Usman, K.O. (2003). Influence of shortage of human resources on the effective instruction of mathematics in secondary schools. The Journal of WCCI Nigeria Chapter Forum, 4(2), 176-18. 